\title{
Metered Powder Dosage Form
}

National Cancer Institute

\section{Source}

National Cancer Institute. Metered Powder Dosage Form. NCI Thesaurus. Code C42961.

A powder contained in a device with valves that permits the dispensing of active and/or inert ing redient(s) upon activation. 